\title{
RADIOGRAPHIC AND HISTOLOGICAL STUDY OF PERENNIAL BONE DEFECT REPAIR IN RAT CALVARIAAFTER TREATMENT WITH BLOCKS OF POROUS BOVINE ORGANIC GRAFT MATERIAL
}

\author{
ESTUDO RADIOGRÁFICO E HISTOLÓGICO DO REPARO DE DEFEITO \\ ÓSSEO PERENE EM CALVÁRIA DE RATO APÓS O TRATAMENTO COM \\ MATERIAL DE ENXERTO ORGÂNICO BOVINO POROSO
}

\author{
Lucele Vieira MARINS \\ Recipient of CNPq scholarship, Department of Biological Sciences, Laboratory of Histology - Bauru Dental School, University of São \\ Paulo, Bauru - SP, Brazil.

\section{Tania Mary CESTARI} \\ Graduate in Biological Sciences, Department of Biological Sciences, Laboratory of Histology - Bauru Dental School, University of São \\ Paulo, Bauru - SP, Brazil. \\ André Dotto SOTTOVIA \\ Post-Graduate student of Oromaxillofacial Surgery and Traumatology - Araçatuba Dental School, UNESP, Araçatuba - SP, Brazil. \\ José Mauro GRANJEIRO, DDs, PhD \\ Associate Professor of the Department of Biological Sciences, Laboratory of Histology - Bauru Dental School, University of São Paulo, \\ Bauru - SP, Brazil. \\ Rumio TAGA, DDs, PhD \\ Full Professor of the Department of Biological Sciences, Laboratory of Histology - Bauru Dental School, University of São Paulo, Bauru - \\ SP, Brazil.
}

\begin{abstract}
$O$ ver the last few years, various bone graft materials of bovine origin to be used in oromaxillofacial surgeries have entered the market. In the present study, we determined the capacity of a block organic bone graft material (Gen-ox, Baumer SA, Brazil) prepared from bovine cancellous bone to promote the repair of critical size bone injuries in rat calvaria. A transosseous defect measuring approximately $8 \mathrm{~mm}$ in diameter was performed with a surgical trephine in the parietal bone of 25 rats. In 15 animals, the defects were filled with a block of graft material measuring $8 \mathrm{~mm}$ in diameter and soaked in the animal's own blood, and in the other 10 animals the defects were only filled with blood clots. The calvariae of rats receiving the material were collected 1, 3 and 6 months after surgery, and those of animals receiving the blood clots were collected immediately and 6 months after surgery. During surgery, the graft material was found to be of easy handling and to adapt perfectly to the receptor bed after soaking in blood. The results showed that, in most animals treated, the material was slowly resorbed and served as a space filling and maintenance material, favoring angiogenesis, cell migration and adhesion, and bone neoformation from the borders of the lesion. However, a foreign body-type granulomatous reaction, with the presence of numerous giant cells preventing local bone neoformation, was observed in two animals of the 1-month subgroup and in one animal of the 3-month subgroup. These cases were interpreted as resulting from the absence of demineralization and the lack of removal of potential antigen factors during production of the biomaterial. We conclude that, with improvement in the quality control of the material production, block organic bone matrix will become a good alternative for bone defect repair in the oromaxillofacial region due to its high osteoconductive capacity.
\end{abstract}

UNITERMS: Xenogenic graft; Bovine cancellous bone; Critical size; Skull; Rats. 


\section{INTRODUCTION}

Although bone tissue possesses a high capacity of spontaneous regeneration, this potential is limited by the size of the defect. Thus, very extensive defects such as those caused by trauma due to a car accident represent a problem to the oromaxillofacial surgeon.

Over the last few years, various surgical procedures using biological or synthetic bone substitutes have been developed for the treatment of these defects in an attempt to promote their closure with new bone tissue that possesses morphological and functional characteristics similar to those of the original tissue.

In reconstructive craniomaxillofacial surgery, autogenous bone continues to be the most widely used graft material due to its favorable biological properties in terms of the formation of new bone tissue ${ }^{1,9,20}$. However, its utilization involves a number of inconveniences, such as the difficulty to predict the final outcome, insufficient amounts of autogenous bone, the need for extensive and long-lasting surgery to obtain the graft and the risk of infection at the donor site $2,11,13,17,21,25$.

With the discovery in the 60s that the organic bone matrix contains morphogenetic protein factors with a high osteoinductive capacity, the use of allogenic bone matrix submitted to chemical treatment in order to eliminate cell and matrix antigens was developed as a new therapeutic alternative for the treatment of perennial bone injuries ${ }^{4-}$ $7,12,16,18,23$. However, the difficulty in obtaining viable human bone in sufficient quantities and the risk of transmission of AIDS and hepatitis B and C, together with the ethical problem of commercializing human tissues, have led several laboratories to develop graft products prepared from bovine bone, which shows the same properties as the allogenic bone matrix.

Despite their widespread utilization, especially in dentistry, these graft materials, both allogenic and xenogenic, produced from cortical bone in the form of particles present some inconveniences, such as their difficult maintenance without the use of a biological membrane inside wide and shallow bone defects, and the lack of porosity in the particles, which impairs vascular and cellular invasion, resorption and bone repair.

In order to overcome these problems, several laboratories have developed bone graft materials from bovine cancellous bone in the form of both blocks and particles. The block graft material has called attention due to its structural aspect of a sponge, easy modeling for placement inside the defect, perfect adaptation to the lateral walls of the defect, and easy use.

In this respect, the objective of the present study was to determine the capacity of block organic bone graft material (Gen-ox ${ }^{\mathrm{TM}}$, Baumer SA, Mogi Mirin - Brazil) produced from bovine cancellous bone to promote the repair of a critical size bone defect surgically created in the calvaria of laboratory rats.

\section{MATERIALAND METHODS}

\section{Animals}

Twenty-five male albino Wistar rats aged 100 days with body mass around 300g, obtained from the Central Animal Laboratory of Bauru Dental School, USP, were used. The animals received water and pelleted Purina ration ad libitum throughout the experiment. The experiment was made in conformity with Ethical Principles of Animal Experimentation of the Brazilian College of Animal Experimentation (COBEA).

\section{Test material}

Bovine bone organic matrix (Gen-ox ${ }^{\mathrm{TM}}$, Baumer SA, Ministry of Health registration \#103.455.00001) is a natural biomaterial obtained from bovine cancellous bone. After rigorous washings for elimination of blood, fat and any impurities, this material is decalcified and dehydrated by the lyophilization process, which impedes the denaturation of proteins while keeps the active principle (Figure 1A-B).

\section{Surgical procedures}

All animals were submitted to skull surgery under general anesthesia with intramuscular injection of xylazine/ ketamine (AgriBrands Ltda ${ }^{\mathrm{TM}}$, Paulinia - Brazil) in order to produce a critical size bone defect ( $>8 \mathrm{~mm}$ in diameter). After trichotomy of the frontoparietal region and vigorous disinfection with iodophor alcohol, the surgical area was isolated and a half moon shaped incision was made in the lining epithelium of the skull with a \#10 surgical knife. The flap was then raised backwards with a Molt spatula, thus widely exposing the bone surface of the skull. Using a surgical trephine measuring $8 \mathrm{~mm}$ in diameter (Figure 2A), a perforation was introduced in the parietal bone under abundant and continuous irrigation with saline solution, crossing the entire diploe and exposing the dura mater at the bottom of the defect (Figure 2B).

The animals were then divided into three groups. In group I (experimental group, 15 animals) the defect was filled with a circular block of graft (Figure 2C) measuring $8 \mathrm{~mm}$ in diameter and with the thickness of the diploe and soaked in the animal's own blood (Figure 2D). In the other two groups of 5 animals each (control group - 0 hour and control group -6 months), the defects were only filled with blood clots. The flap of each animal was then placed in position and closed with \#3 nylon sutures (Ethicon $^{\mathrm{TM}}$, Johnson \& Johnson, Sao Jose dos Campos, Brazil).

\section{Histological procedures}

The rats were sacrificed with an overdose of anesthetic agent according to the treatment period of the control groups and 1, 3 and 6 months after surgery for the experimental group. The skullcaps with overlaying skin were collected and fixed in $10 \%$ formalin in phosphate buffer for one week, radiographed, demineralized in Morse solution (50\% formic 

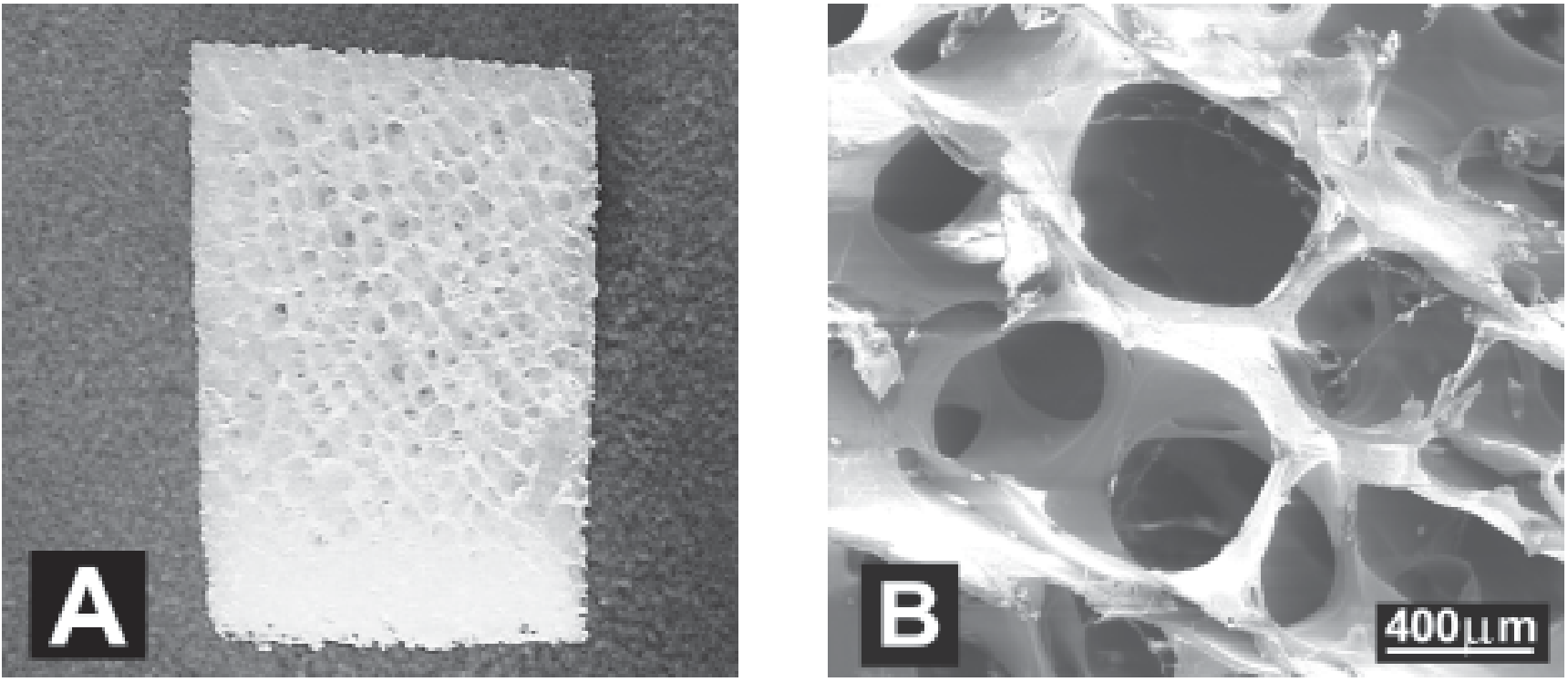

FIGURE 1.- Macroscopic (A) and scanning electron microscopic (B) views of organic bovine bone in block showing various interconnected pores
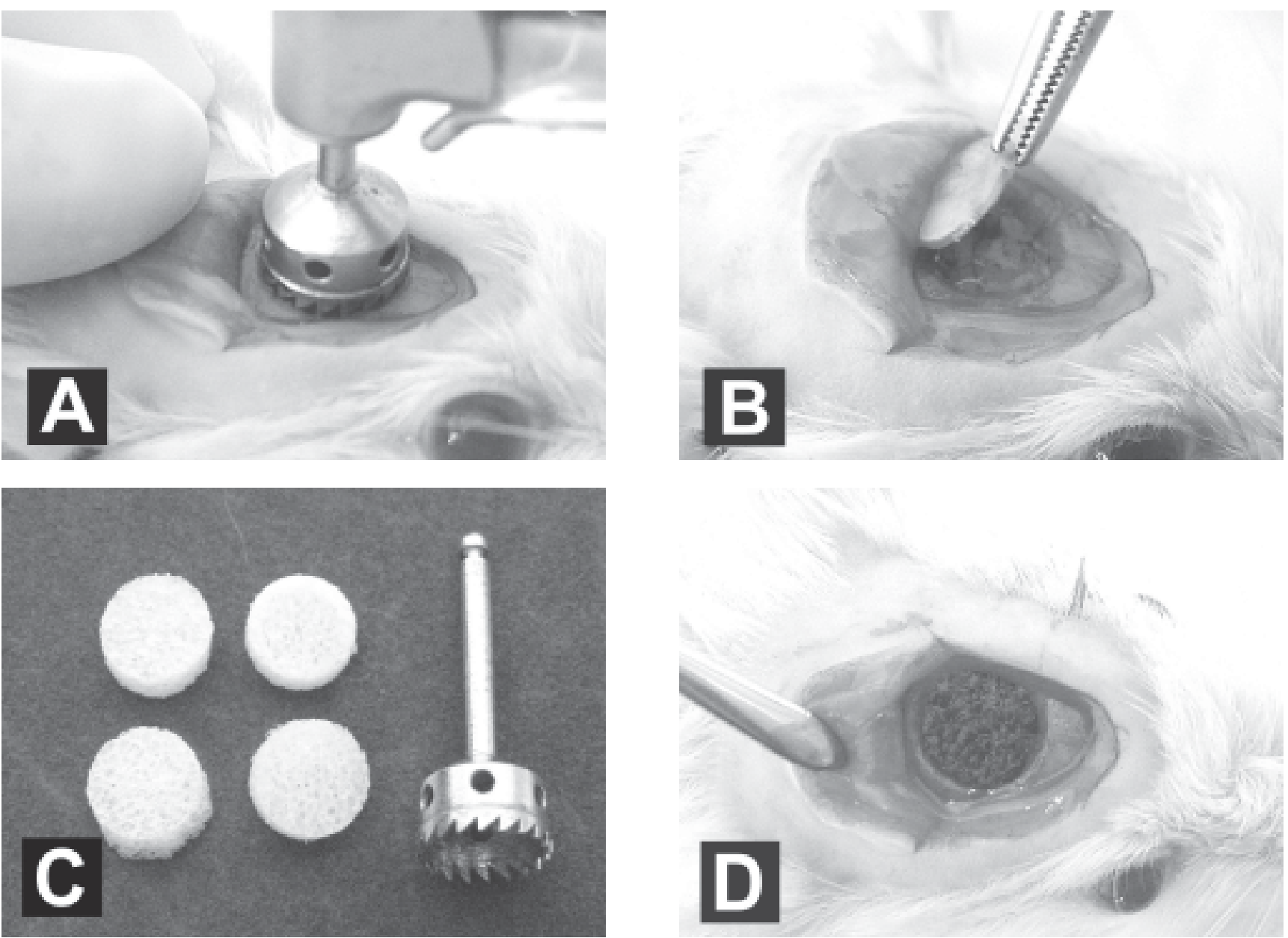

FIGURE 2.- Surgical procedures; A) perforation of the parietal bone with trephine; B) exposure of the dura mater at the bottom of the defect; $\mathbf{C}$ ) defect filled with a circular block of organic bovine bone; and E) replacement and suture of soft tissue 
acid and 20\% sodium citrate, 1:1) for 40 days, dehydrated in ethanol, cleared with xylene and embedded in HistosecMerck $^{\mathrm{TM}}$. The specimens were cut in the laterolateral direction into 5 - $\mu \mathrm{m}$ thick semi-serial sections and stained with hematoxylin-eosin.

\section{Morphometric analysis of the radiographic images}

The radiographic images were digitized using a Hewlett Packard ScanJet 4c/T scanner and transferred to a digitized image analysis system consisting of Kontron KS 300 software (Kontron Electronic GmbH ${ }^{\mathrm{TM}}$, Carl Zeiss, Germany) and an IBM computer. Using this system, the initial area of the lesion (Ai) was determined in the 0 -hour control group and the area without bone formation (A) was measured in the other groups. The area of the defect repaired with newly formed bone tissue (Ao) was calculated for each animal by equality, i.e., $\mathrm{Ao}=\mathrm{Ai}-\mathrm{A}$.

\section{Histological analysis}

All histological sections were analyzed with an Axioscop $^{\mathrm{TM}}$ (Carl Zeiss, Germany) and the following events were determined: presence of blood clots and inflammatory infiltrates, intensity of angiogenesis, formation of granulation tissue, resorption of graft material, reorganization of the periosteum and bone remodeling. Photomicrographs were obtained with a Zeiss-Axioskop photomicroscope.

\section{Statistical analysis}

The morphometric results were compared between the different groups by analysis of variance (ANOVA) and by a pairwise multiple comparison procedure (Student- NewmanKeuls test) using the Sigma Stat Jandel ${ }^{\mathrm{TM}}$ Scientific Software for Windows, at a significance level of $5 \%$.

\section{RESULTS}

\section{Radiographic and morphometric results}

The radiographic images obtained for the 0-hour and 6month control animals and the animals in the experimental groups, and the graph of bone defect total area obtained by analysis of the images are shown in Figures 3, 4 and 5, respectively.

The mean area of the defects in the 0 -hour control group was $52.5 \mathrm{~mm}^{2}$ (Figure 3A-E). One month after surgery, the mean area of the experimental group was $49.7 \mathrm{~mm}^{2}$, with no significant difference $(\mathrm{P}>0.05)$ compared to the initial group (compare Figures 3A-E and 4A-E). A 60\% decrease $(\mathrm{P}<0.05$ ) in the mean area of the defect compared to the 0 -hour group was observed 3 months after the surgical treatment, with the area measuring on average $25.6 \mathrm{~mm}^{2}$. Radiographic analysis of this subgroup showed that this reduction was due to bone formation at the border of the defect in two cases (Figures 4G and I) and also to the large bone formation inside the defect in one case (Figure 4F). It should be noted that the latter animal also showed the highest percentage of closure of the defect throughout the experiment. At 6 months after surgery, although significant closure of the defect was observed in three cases (Figures 4K-M), no closure compared to the previous period was observed in two cases (Figures 4N, O), with the mean area of the defect $\left(19.9 \mathrm{~mm}^{2}\right.$ ) not differing from that obtained for the 3-month subgroup $(\mathrm{P}>0.05)$. The mean area of the defect was $39 \%$ smaller $(\mathrm{P}<0.05)$ in the 6-month experimental subgroup (Figure $4 \mathrm{~K}$ O) compared to the 6-month control group (Figs. 3F-J).

\section{Morphologic results}

\section{Experimental group}

At 1 month after surgery, the defect was found to be filled with graft material in an advanced state of resorption by mononuclear cells, showing intertrabecular porosities

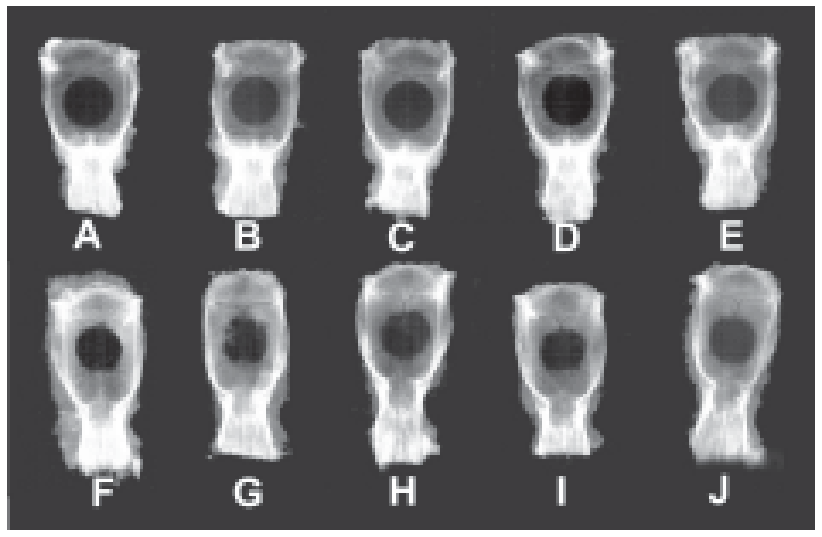

FIGURE 3.- Radiographic images of 0-hour (A-E) and 6month (F-J) control groups

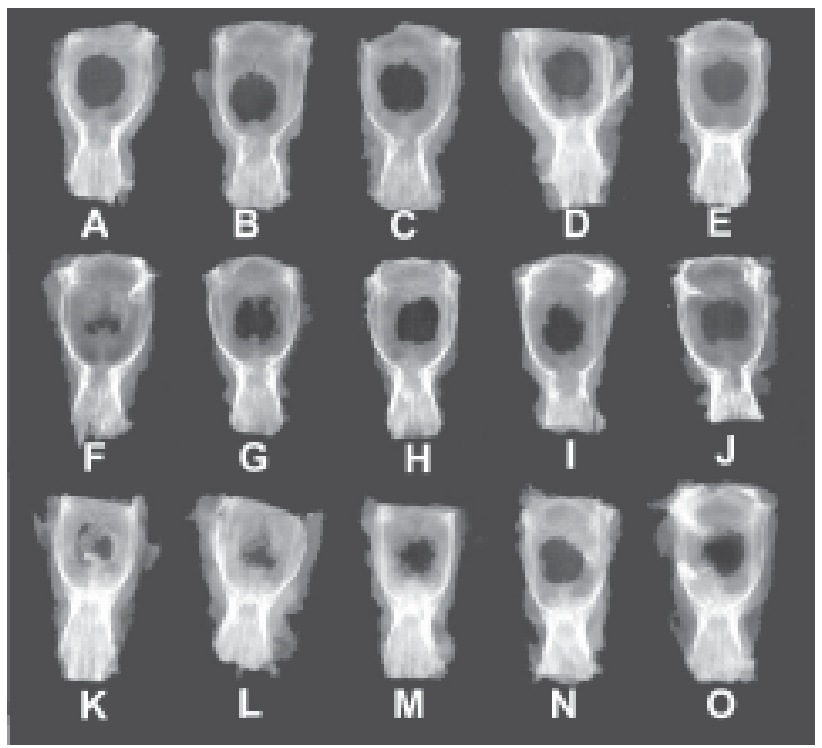

FIGURE 4.- Radiographic images of 1-month (A-E), 3-month (F-J) and 6-month (L-P) experimental groups 
filled with tissue rich in cells and vessels (Figure 6A). Newly formed bone tissue was observed associated with some trabeculae undergoing resorption (Figure 6B). Bone neoformation was also observed at the border of the defects, especially in the region of the dura mater. In two animals of this subgroup, giant multinucleated cells were found associated with the trabecular surface of the graft, suggesting resorptive activity. These animals also showed some focal areas of foreign body-type granulomatous inflammation, characterized by a set of epithelioid macrophages, some of which multinucleated, surrounded by a lymphocyte chain (Figure 6C).

At 3 months after surgery, defects filled with large islets of newly formed bone, either separated by connective tissue or fused, and fragments of graft matrix captured inside this tissue or dispersed within the existing connective tissue were observed in two animals. In one of these animals, this mass of primary bone tissue filled almost the entire defect (Figure 6D). Less bone neoformation at the border of the defect and a larger number of graft fragments were observed in the remaining animals. One of these animals showed a foreign body-type granulomatous reaction close to the matrix fragments (Figure 6E).

No marked morphologic differences compared to the previous period were observed at the end of the 6-month period, besides a small increase in the amount of newly formed bone tissue at the border or inside the defect and greater organization of this tissue, resembling the original tissue that had been lost.

\section{Six-month control group}

At 6 months after surgery, the defects showed a small amount of newly formed bone tissue from their borders and the opening of the defect was found to be filled with fibrous connective tissue in all animals of the group (Figure 6F). Focal formation of bone tissue together with fibrous tissue was observed in some cases.

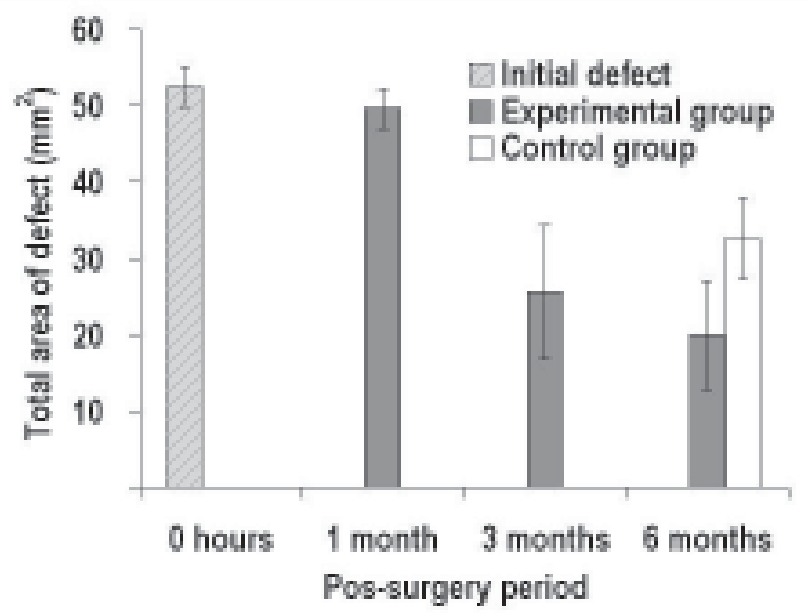

FIGURE 5.- Area of bone defect $\left(\mathrm{mm}^{2}\right)$ obtained in the radiographic images. Mean \pm standard error of 5 animals

\section{DISCUSSION}

One of the dilemmas of oromaxillofacial surgeons is the question on how to treat extensive bone injuries accompanied by tissue loss. Although autogenous grafts are commonly employed in these cases, the need for additional intervention increases the duration of surgery and the risk of infections, pain and discomfort at the donor site. During the last few years, several bone graft materials produced from bovine bone, with physicochemical characteristics similar to those of human bone, have been developed for use in oral and orthopedic surgeries as an alternative to autogenous grafts. Commercially, bone graft biomaterials of bovine origin differ in terms of their cortical or cancellous bone origin, organic or inorganic composition, and physical presentation in the form of particles or blocks.

In the present study we analyzed the process of bone repair in defects treated with block organic graft material produced from bovine cancellous bone (Gen-ox). For this purpose, we used critical size bone defects experimentally produced in rat calvaria as the biological model, which has been considered by many researchers to be the ideal model for testing bone graft materials in the craniomaxillofacial region ${ }^{3,8,19}$.

With respect to the utilization of the material, we noted during the surgical phase of the experiment that the block organic matrix is of easy handling and application, adapting easily and perfectly to the receptor bed after soaking in blood.

It should be emphasized that most animals presented an excellent response to implantation of the graft material, with the absence of inflammation during the different periods studied and a significant formation of bone tissue compared to control animals. However, the presence of foci of a foreign body, granulomatous reaction close to the graft, accompanied by agglomerates of macrophages and giant cells surrounded by lymphocytes and almost no new bone formation, was observed in a few cases 1 and 3 months after surgery. The presence of multinucleated giant cells and a foreign body-type inflammatory reaction are known to markedly inhibit new bone formation ${ }^{10,14}$. The few cases observed here were probably due to incomplete decalcification of the material during its production, with matrix antigens remaining in the material. This inference is based on the fact that some multinucleated giant cells were intimately attached to the trabecular surface of the graft matrix and presented evidence of resorptive activity. Another possibility is the presence of lipid residues in the graft. Bovine spongiform cancellous bone used during the production of the material is known to be rich in adipose tissue (yellow bone marrow), porosity and very small canals (300-500mm), a fact that makes its complete cleaning difficult even when submitting it to drastic treatments with fat solvents such as chloroform and ethyl ether.

The other bone defects filled with a block of demineralized cancellous bone matrix showed intense bone neoformation as early as 1 month after surgery, with bone mainly being formed from the borders of the defect and 
inside the graft close to the surface of some trabeculae. After 3 months, a large part of the defect was found to be filled with new bone in the form of coalescent islets in the process of remodeling and showing fragments of the graft matrix. At the end of 6 months, although no significant
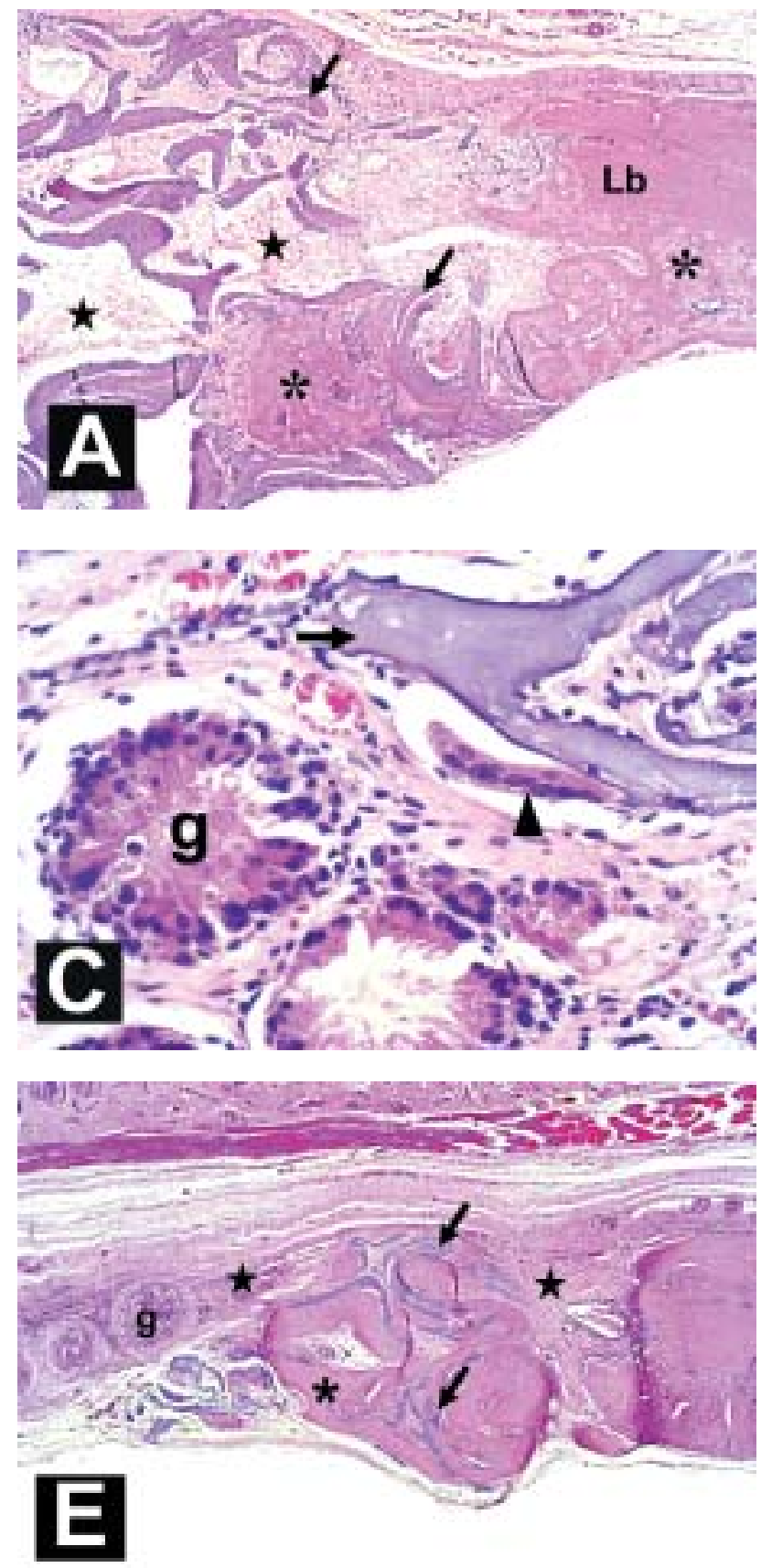

increase in closure of the area of the defect was observed compared to the previous period, the organization of the newly formed bone tissue was closer to that of the original tissue.

Radiographic and histological analysis showed that most
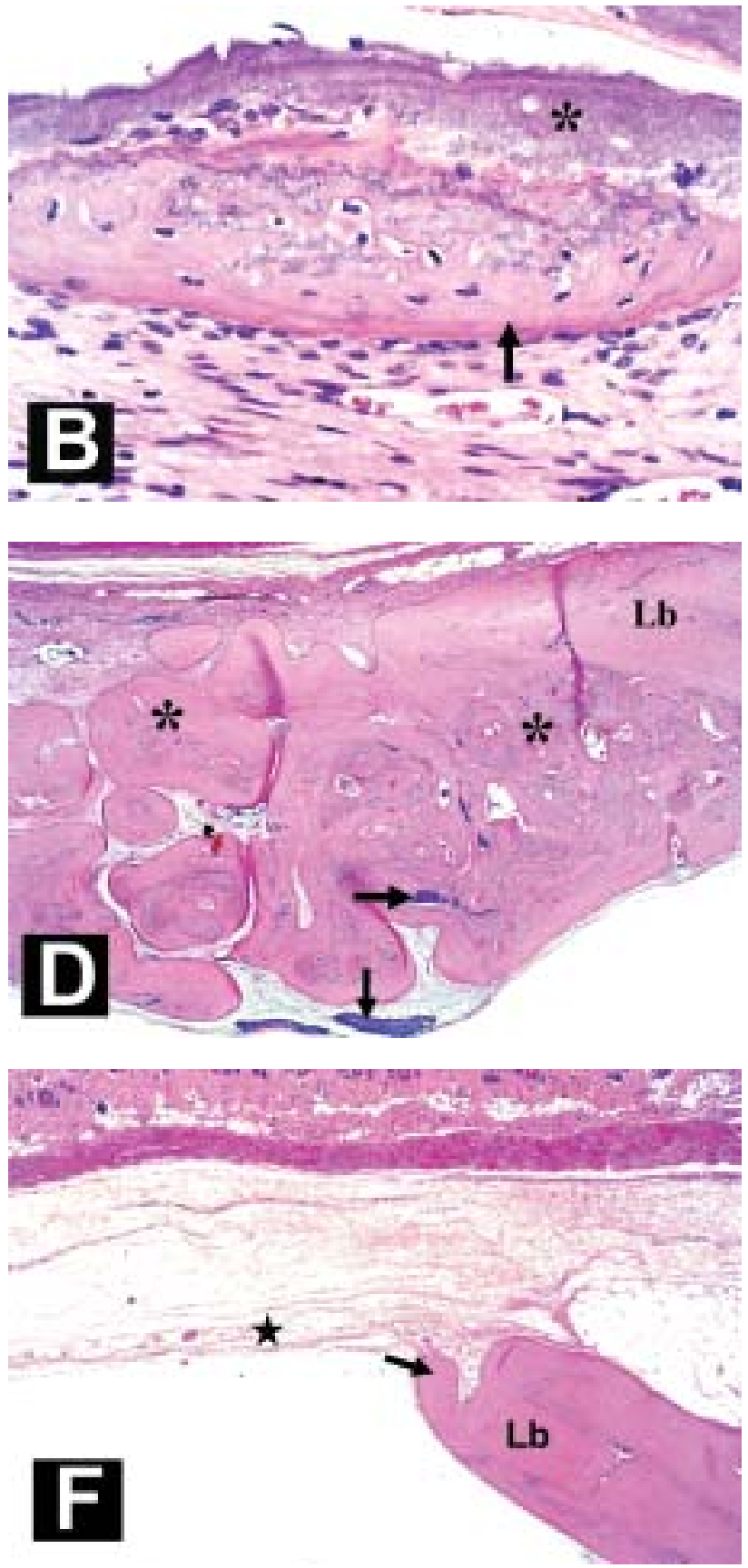

FIGURE 6.- Histological images: (A-C) 1-month experimental group; A) intertrabecular porosities filled with connective tissue (stars) and newly formed bone tissue (asterisks) in the lesion border (Lb) and associated with the trabecular surface of matrix (arrow); B) detail of bone tissue (arrow) associated with the matrix surface (asterisk); and C) giant multinucleated cells (arrowhead) in the matrix (arrow) surface and areas of foreign body-type granuloma (g). (D-E) 3-month experimental groups; D) defect filled with great amount of neoformed bone tissue (asterisk) and fragments of matrix (arrows); and E) defect filled with small islets of neoformed bone (asterisk) and fibrous connective tissue (stars) showing foreign body-type granulomas (g). (F) 6-month control group, defect filled with connective tissue (star) and exhibiting small bone formation (asterisk) in the border lesion (Lb). Hematoxilin-eosin, 34x and 340x magnification. 
of the new bone was formed at the borders of the defects, indicating a large osteoconductive capacity of this type of graft material, probably due to its chemical composition (90\% collagen type I) and its structural characteristics with pores and inter-pore connections resembling those of the bone receiving area. Focal osteogenesis inside the graft, in addition to centripetal bone formation, was observed in some animals, especially those showing greater closure. Although some researchers have reported that bone matrix originating from marrow does not possess sufficient bone morphogenetic proteins, the present findings suggest the existence of bone induction factors in some segments of the graft trabeculae at an amount sufficient to induce focal osteogenesis.

With respect to its high osteoconductive capacity, i.e., to favor cell adhesion, migration and proliferation at the graft site, the few studies using block organic bone matrix originated from bovine cancellous bone have directed its application to tissue-engineered cartilage repair, mainly as a scaffold for autogenous chondrogenic cells originating from the perichondrium ${ }^{15,22,24}$.

\section{CONCLUSION}

Based on the present results, we conclude that, with improvement in the quality control of the material production, block organic matrix of bovine cancellous bone marrow will become a good alternative for the repair of bone defects in the oromaxillofacial region due to its high osteoconductive capacity and its potential as an ideal carrier for recombinant bone morphogenetic proteins.

\section{RESUMO}

Nos últimos anos, vários materiais de origem bovina para enxerto ósseo têm sido lançados no comércio para serem utilizados em cirurgias bucomaxilofaciais. Na presente pesquisa avaliamos a capacidade de um material de enxerto ósseo orgânico em bloco (Gen-ox, Baumer SA - Brasil) preparado à partir de osso medular bovino, em promover a reparação de lesões ósseas de tamanho crítico em calvária de ratos. Uma lesão trans-óssea de aproximadamente $8 \mathrm{~mm}$ de diâmetro foi realizada com trefina cirúrgica nos ossos parietais de 25 ratos, sendo que em 15 os defeitos foram preenchidos com bloco de $8 \mathrm{~mm}$ de diâmetro do material de enxerto, embebida com sangue do próprio animal e em 10 somente com coágulo sanguíneo. As calvárias dos ratos tratados com o material foram coletadas após 1, 3 e 6 meses após as cirurgias e dos tratados com coágulo sanguíneo, imediatamente após as cirurgias e decorridos 6 meses. Durante as cirurgias verificamos que esse material enxertado é de fácil manuseio e se adapta perfeitamente ao leito receptor após sua embebição com sangue. Os resultados obtidos mostraram que na maioria dos casos tratados, o material foi reabsorvido lentamente e serviu como material de preenchimento e mantenedora de espaço, favorecendo a angiogênese, migração e adesão celular e a neoformação óssea à partir das bordas da lesão. No entanto, em 2 casos no subgrupo tratado - 1 mês e 1 caso no subgrupo tratado 3 meses, ocorreu a presença de reação granulomatosa tipo corpo estranho com a presença de inúmeras células gigantes, que inibiu a neoformação óssea local. Esses casos foram interpretados como decorrentes de falhas na desmineralização e na retirada de potenciais fatores antigênicos durante a produção do biomaterial. Concluímos que com um aprimoramento do controle de qualidade na linha de produção do material, a matriz orgânica medular em bloco poderá ser uma boa alternativa para ser usada no reparo de defeitos ósseos na região buco-maxilofacial, devido a sua alta capacidade osteocondutora.

UNITERMOS: Reparo ósseo; Osso medular bovino; Defeito perene; Calvária; Ratos.

\section{REFERENCES}

1- Aaboe M, Pinholt EM, Hjorting- Hansen E. Healing of experimentally created defects: a review. Br J Oral Maxillofac Surg 1995; 33(5): 312-8.

2- Aichelmann-Reidy ME, Yukna RA. Bone replacement grafts. The bone substitutes. Dent Clin North Am 1998 ;42(3):491-503.

3- Bosch C, Melsen B, Vargervik K. Importance of the criticalsize bone defect in testing bone-regenerating materials. J Craniofac Surg 1998; 9(4):310-6.

4- Glowacki J, Altobelli D, Mulliken JB. Fate of mineralized and demineralized osseous implants in cranial defects. Calcif Tissue Int 1981; 33(1):71-6.

5- Glowacki J, Kaban LB, Murray JE, Folkman J, Mulliken JB. Application of the biological principle of induced osteogenesis for craniofacial defects. Lancet 1981; 1(8227):959-62.

6- Glowacki J, Mulliken JB. Demineralized bone implants. Clin Plast Surg 1985; 12(2):233-41.

7- Habal MB. Reconstruction of a large congenital cranioorbital defect with a species-specific demineralized bone implant. J Craniofac Surg 1992; 3(2):113-8.

8- Hollinger JO, Kleinschmidt JC. The critical size defect as an experimental model to test bone repair materials. : J Craniofac Surg 1990; 1(1):60-8.

9- Isaksson S, Alberius P, Klinge B, Jonsson J, Hallberg E, Wendel $M$. Regenerative response to membranous and enchondral lyophilized allogeneic bone in rabbit skull defects. Scand J Plast Reconstr Surg 1992; 26 (2): 147-53.

10- Lassus J, Salo J, Jiranek WA, Santavirta S, Nevalainen J, Matucci-Cerinic M, Horak P, Konttinen Y. Macrophage activation results in bone resorption. Clin Orthop 1998; 352:7-15.

11- Moore WR, Graves SE, Bain GI. Synthetic bone graft substitutes. ANZ J Surg 2001; 71(6):354-61. 
12- Mulliken JB, Glowacki J, Kaban LB, Folkman J, Murray JE. Use of demineralized allogeneic bone implants for the correction of maxillocraniofacial deformities. Ann Surg 1981; 194(3):366-72.

13- Nasr HF, Aichelmann-Reidy ME, Yukna RA. Bone and bone substitutes. Periodontol 2000 1999; 19:74-86.

14- Neale SD, Athanasou NA. Cytokine receptor profile of arthroplasty macrophages, foreign body giant cells and mature osteoclasts. Acta Orthop Scand 1999; 70(5):452-8.

15- Pirsig W, Bean JK, Lenders H, Verwoerd CD, Verwoerd-Verhoef HL. Cartilage transformation in a composite graft of demineralized bovine bone matrix and ear perichondrium used in a child for the reconstruction of the nasal septum. Int J Pediatr Otorhinolaryngol 1995; 32(2):171-81.

16- Reddi AH, Huggins C. Biochemical sequences in the transformation of normal fibroblasts in adolescent rats. Proc Natl Acad Sci U S A 1972; 69(6):1601-5.

17- Salyer KE, Bardach J, Squier CA, Gendler E, Kelly K. Cranioplasty in the growing canine skull using demineralized perforated bone.Plast Reconstr Surg 1995; 96( 4): 770-9.

18- Salyer KE, Gendler E, Squier CA. Long-term outcome of extensive skull reconstruction using demineralized perforated bone in Siamese twins joined at the skull vertex. Plast Reconstr Surg 1997; 99(6):1721-6.

19- Schmitz JP, Hollinger JO. The critical size defect as an experimental model for craniomandibulofacial nonunions. Clin Orthop 1986; 205:299-308.

20- Schwarz N, Schalag G, Thurnher M, Eschberger J, Dinges Hp, Redl H. Fresh autogeinec, frozen allogeneic, and decalcified allogeneic bone grafts in dogs. J Bone Joint Surg Br 1991; 73 (5): 787-90.

21- Seiler JG 3rd, Johnson J. Iliac crest autogenous bone grafting: donor site complications. J South Orthop Assoc 2000; 9(2):91-7.

22- ten Koppel PG, van Osch GJ, Verwoerd CD, Verwoerd-Verhoef HL. Efficacy of perichondrium and a trabecular demineralized bone matrix for generating cartilage. Plast Reconstr Surg 1998; 102(6):2012-20; discussion 2021.

23- Urist MR. Bone: formation by autoinduction. Science 1965; 150(698):893-9.

24- Verwoerd-Verhoef HL, Bean JK, van Osch GJ, ten Koppel PG, Meeuwis JA, Verwoerd CD. Induction in vivo of cartilage grafts for craniofacial reconstruction. Am J Rhinol 1998; 12(1):2731.

25- Younger EM, Chapman MW. Morbidity at bone graft donor sites. J Orthop Trauma 1989; 3(3):192-5.
Recebido para publicação: 05/08/2003

Enviado para reformulações: 06/10/2003

Pronto para publicação: 09/10/2003

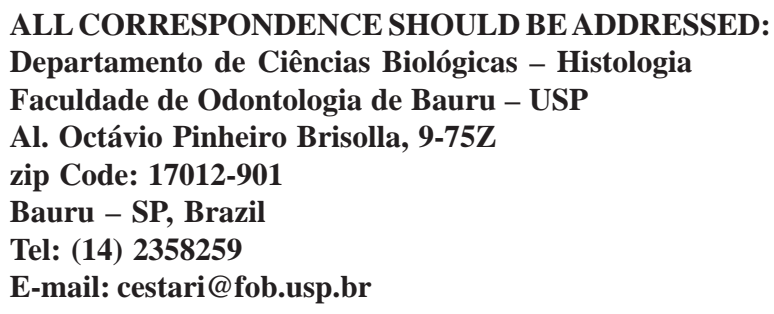

